\title{
Surveillance of a federally protected freshwater fish using loop-mediated isothermal amplification (LAMP) and eDNA
}

\author{
Kayla Fast ${ }^{1}$, Anakela Popp ${ }^{2}$, Patrick O’Neil ${ }^{3}$, Stuart McGregor ${ }^{3}$, and Michael Sandel ${ }^{1}$ \\ ${ }^{1}$ University of West Alabama \\ ${ }^{2}$ Georgia Department of Natural Resources \\ ${ }^{3}$ Geological Survey of Alabama
}

July 27, 2020

\begin{abstract}
Environmental DNA (eDNA) has increasingly been used in the surveillance of imperiled aquatic species. Despite recent efforts in drawing genetic material from the environment, there are still pitfalls surrounding this field. We created a novel protocol which implements loop-mediated isothermal amplification (LAMP) to detect target DNA. Our methods are applied here in the surveillance of Etheostoma trisella, the Trispot Darter, a freshwater fish that recently received protection under the U.S. Endangered Species Act. Water samples $(\mathrm{n}=256)$ were collected at sites in Alabama and Georgia to determine whether $E$. trisella still occupies historic sites and whether it inhabits previously unknown areas. We found evidence of E. trisella presence in 69 water samples while 187 were negative. Our LAMP protocol is capable of amplifying low quantities of DNA in the water, and is a robust technique for freshwater species surveillance. Verification of positive results from eDNA experiments is essential to confirm reaction reliability. Application of methods such as ours are necessary for recognizing species under threat that require conservation.
\end{abstract}

Surveillance of a federally protected freshwater fish using loop-mediated isothermal amplification (LAMP) and eDNA

Running Head: Surveillance of protected fish

Kayla M. Fast ${ }^{1}$, Anakela Popp ${ }^{2}$, Patrick E. O'Neil ${ }^{3}$, Stuart W. McGregor ${ }^{3}$, Michael W. Sandel ${ }^{1}$

${ }^{1}$ Department of Biological and Environmental Sciences, the University of West Alabama, Livingston, Alabama, USA

${ }^{2}$ Georgia Department of Natural Resources, Wildlife Resources Division, Social Circle, GA, USA

${ }^{3}$ Geological Survey of Alabama, Tuscaloosa, AL, USA

Correspondence: Kayla M. Fast and Michael W. Sandel, Department of Biological and Environmental Sciences, the University of West Alabama, Livingston, Alabama, USA. Email: kfast@uwa.edu (KMF) and msandel@uwa.edu (MWS)

\section{ABSTRACT}

Environmental DNA (eDNA) has increasingly been used in the surveillance of imperiled aquatic species. Despite recent efforts in drawing genetic material from the environment, there are still pitfalls surrounding this field. We created a novel protocol which implements loop-mediated isothermal amplification (LAMP) to detect target DNA. Our methods are applied here in the surveillance of Etheostoma trisella, the Trispot Darter, a freshwater fish that recently received protection under the U.S. Endangered Species Act. Water 
samples $(\mathrm{n}=256)$ were collected at sites in Alabama and Georgia to determine whether E. trisella still occupies historic sites and whether it inhabits previously unknown areas. We found evidence of E. trisellapresence in 69 water samples while 187 were negative. Our LAMP protocol is capable of amplifying low quantities of DNA in the water, and is a robust technique for freshwater species surveillance. Verification of positive results from eDNA experiments is essential to confirm reaction reliability. Application of methods such as ours are necessary for recognizing species under threat that require conservation.

Keywords

\section{Etheostoma trisella}

environmental DNA

loop-mediated isothermal amplification

freshwater

\section{INTRODUCTION}

The conservation of imperiled species requires an understanding of current population stability and distribution. However, the surveillance of aquatic species via the employment of traditional methods such as netting and electrofishing are labor intensive, expensive, and disruptive to the species of conservation concern (Jerde et al., 2011). Many species that require monitoring are rare, and, in fact, the probability of detecting aquatic taxa using traditional methods is low when species density falls below a specific threshold (Dejean et al., 2012). Furthermore, due to permitting restrictions, it is difficult to rapidly assess populations of species protected by law. Some studies have found that sampling methods such as electrofishing do not accurately determine the abundance of targeted taxa despite their invasive nature (Wilcox et al., 2016). Several eDNA studies report that published methods did not capture the true diversity or abundance of taxa known from traditional sampling (Cilleros et al., 2019; Drinkwater et al., 2019). As such, a noninvasive, supplemental method is required in order to monitor and provide protection to as many imperiled species as possible.

Environmental DNA (eDNA) is the genetic material found in environmental samples such as water, sediment, and air. Representing a conglomeration of genetic material sourced to different organisms, eDNA molecules originate from extracellular DNA (i.e., natural cell death followed by cell lysis), cellular DNA (e.g., epithelial cells, mucus, and feces) or microbial organisms (Díaz-Ferguson \& Moyer, 2014; Nagler et al., 2018; Pietramellara et al., 2009; Taberlet et al., 2012). DNA from environmental sources was first utilized in the 1980's for the extraction of microbial DNA from sediment and later for bacterial biomass assessment (Ogram et al., 1987; Paul et al., 1996). Environmental DNA is now used in aquatic systems to detect invasive species, monitor populations of threatened taxa, and trace fecal contaminants (Díaz-Ferguson \& Moyer, 2014; Goldberg et al., 2011; Jerde et al., 2011; Layton et al., 2006).

The detection of target eDNA using traditional polymerase chain reaction (PCR) and quantitative PCR (qPCR) at natural sites has shown limited applicability in both freshwater and marine habitats (Foote et al., 2012; Grey et al., 2018). In an effort to increase the utility of eDNA, we have developed an eDNA detection method that applies loop-mediated isothermal amplification (LAMP). Previous authors have prospected the utility of LAMP for animal eDNA detection, but this study is the first to demonstrate feasibility for freshwater fishes (Lee, 2017; Rees et al., 2014). LAMP amplifies target sequences with high specificity by initially binding four different primers to six complementary regions of the target DNA; annealing of two primers to four target regions maintains specificity as amplification progresses (Notomi et al., 2000). This method uses a Bst DNA polymerase under isothermal conditions to produce multiple stem-loop DNA structures (Notomi et al., 2000). Furthermore, LAMP has the capability of amplifying small quantities of target DNA with detection possible with as few as six copies in solution during experimentation (Notomi et al., 2000).

While the use of genetic material isolated from nonliving sources for the detection of targeted taxa is not novel, our custom molecular methods are. We present here the application of our new method to the surveillance of Etheostoma trisella (Percidae) populations.E. trisella, the Trispot Darter, is a small, freshwater fish endemic 
to the Coosa River system of northwestern Georgia, southeastern Tennessee, and northeastern Alabama (Page \& Burr, 2011). The currently understood range in Georgia and Tennessee includes the Conasauga River system upstream of the confluence with the Coosawattee River including Mill Creek and below Carter's Lake, and the Oostanaula River between Arumuchee Creek and Calhoun (Boschung \& Mayden, 2004; Rare Species Status Maps , 2020). In Alabama, E. trisella has recently been recovered in Little Canoe Creek and Ballplay Creek (FishMap.Org, 2018; O'Neil et al., 2009). Etheostoma trisella occupies a specialized niche and migrates between two seasonally interconnected habitats (Ryon, 1986). During the non-breeding season (mid-April to mid-October), E. trisella populates peripheral zones characterized by the presence of gravel, vegetation, and a slow moving current. Seasonal rainfall allows the darter to migrate upstream to the breeding grounds where they spawn from January to March. This habitat consists of streams in seepage waters of pastures and floodplains containing high amounts of vegetation. Given that E. trisella has a severely limited distribution and is highly impacted by anthropogenic activity, the darter was listed as "Threatened" under the Endangered Species Act (ESA) in 2019 (Endangered and Threatened Wildlife and Plants; Threatened Species Status for Trispot Darter, 2018). Therefore, surveillance of E. trisella populations is essential in understanding how to best implement conservation efforts.

\section{MATERIALS AND METHODS}

\subsection{Sample Collection}

We collected environmental water samples $(\mathrm{n}=256)$ during 2019 (January-March) at 136 sites encompassing 17 watersheds in Georgia and Alabama, USA (Figure 1). Collection sites were chosen to collectively satisfy the following criteria: 1) localities of documented E. trisella captures, 2) localities proximal to documented E. trisella captures, and 3) localities where E. trisella have not been documented. For each collection, two sealed 0.5L plastic water bottles were emptied of the manufacturer's contents and filled with environmental water. Negative field controls were implemented as suggested by Goldberg et al. (2016).

\section{2 eDNA Extraction}

We captured eDNA from environmental water samples by filtering through Whatman Microfiber Filters (GE Healthcare, Chicago, IL, USA) housed in Nalgene Analytical Test Filter Funnels (Thermo Fisher Scientific, Waltham, MA, USA) using the Geopump Peristaltic Pump (Geotech Environmental Equipment, Denver, CO, USA). Duplicate water samples were combined during filtration. Filters containing residual particles were cut into halves; one half was stored in $70 \%$ ethanol at $4{ }^{\circ} \mathrm{C}$ and the other half used immediately in DNA extraction. DNA extraction was performed using the Qiagen DNeasy Blood and Tissue Kit (Qiagen, Hilden, Germany) and the QIAshredder (Qiagen, Hilden, Germany). DNA quality and quantity were determined using standard gel electrophoresis on a 1.5\% agarose gel and a NanoDrop 2000 Spectrophotometer (Thermo Fisher Scientific, Waltham, MA, USA). Purified eDNA was stored at $4{ }^{\circ} \mathrm{C}$. Filtration of water and extraction of eDNA were performed in a lab environment cleaned with a $10 \%$ bleach solution.

\section{3 eDNA Detection}

We detected E. trisella presence by implementing a custom LAMP protocol. LAMP primers were designed in PrimerExplorer (v. 5) within the mitochondrial genome with specificity for the E. trisellacytochrome $b$ (cyt $b$ ) gene (Table 1) and optimized in a temperature titration (LAMP Primer Designing Software:PrimerExplorer , 2015; Sandel et al., 2020). Primer specificity was verified using Primer-BLAST; our external primers alone yielded $E$. trisella as the only expected target (Ye et al., 2012). LAMP was performed with the following specifications suggested by the manufacturer: $12.5 \mu$ L LavaLAMP DNA Master Mix (2X; Lucigen, Middleton, WI, USA), 2.5 $\mathrm{L}$ target-specific primer assay (Table 1), 1.0 $\mu \mathrm{L}$ green fluorescent dye (Lucigen, Middleton, WI, USA), bovine serum albumin (0.4 mg/mL; Thermo Fisher Scientific, Waltham, MA, USA), 7.5 $\mu$ L Invitrogen UltraPure DNase/RNase-Free Distilled Water (Thermo Fisher Scientific, Waltham, MA, USA), and 1.0 $\mu \mathrm{L}$ template DNA for a total reaction volume of $25.0 \mu \mathrm{L}$. Reactions were performed on a Stratagene Mx3000P (Agilent Technologies, Santa Clara, CA, USA) under the following conditions: 4 min $90^{\circ} \mathrm{C}$ preheat, $30 \mathrm{~min}$ $74^{\circ} \mathrm{C}$ temperature hold, standard dissociation curve, and $5 \min 95^{\circ} \mathrm{C}$ enzyme deactivation. All reactions were performed in triplicate including positive and negative controls. To ensure that our primers amplify different 
genetic populations of E. trisella, we performed our LAMP protocol on a subset of fish representing three genetically distinct populations (unpublished data). Although our primers were designed to target $E$. trisella only, we determined that two species of darter could potentially be cross-amplified. To account for this possibility, we screened DNA samples from E. jordani and E. rupestre, genetically similar species of darter that may be detectable in our water samples.

Results were visualized using standard gel electrophoresis on a $1.5 \%$ agarose gel, amplification plots and dissociation curves on the Stratagene Mx3000P, and quantitative electrophoresis on a QIAxcel Advanced System (Qiagen, Hilden, Germany). We performed quantitative electrophoresis using the QIAxcel DNA High Resolution Kit (Qiagen, Hilden, Germany) combined with a 15bp/600bp QX Alignment Marker (Qiagen, Hilden, Germany) and 25-500bp QX DNA Size Marker (5ng/ $\mu \mathrm{L})$ under the manufacturer's suggested 0H800 method. A positive status was assigned to experimental samples if they produced DNA segments comparable in size to at least three of the five segments characterizing the positive control. In addition, samples were only deemed positive upon reaching a positive result in a second replicate (Mahon et al., 2013). A subset of positive products was purified using the QIAquick Gel Extraction Kit (Qiagen, Hilden, Germany) and sequenced with a SimpleSeq Kit (Eurofins Genomics, Louisville, KY, USA) to verify template amplification. We used NCBI BLAST to determine the origin of each DNA fragment (Altschul et al., 1990). Statistical analyses were performed using the R Programming Language including Fisher's Exact Tests and covariance to determine which factors may influence detection, if any (R Core Team, 2018).

\section{RESULTS}

After screening environmental water samples, 187 samples were found to be negative for E. trisella presence and 69 positive (Figure 1). At sites in Alabama, $24.5 \%$ of water samples screened positive $(\mathrm{n}=151)$ while $30.5 \%$ of samples in Georgia were positive $(\mathrm{n}=105)$. Water samples from different states were obtained by different groups of collectors, and we show that detection of E. trisella was not influenced by collector $(\mathrm{p}=$ 0.3911). However, the date of water collection did influence detection $(\mathrm{p}<0.05)$. Post hocpairwise analyses indicate that detections were lowest during the beginning of our collection period (January) and increased in February through March $(\mathrm{p}<0.05)$. The sampling scheme (i.e., north/south or east/west) did not confound this temporal trend $(\mathrm{Cov}=-0.11921)$.

Our primers amplified all genetic lineages of E. trisella tested. With several mismatched sites in our primers, amplification of DNA belonging to other Etheostoma species was not a source of false positives as neither E. jordani nor E. rupestre amplified using our E. trisella primer set. Sequence data confirmed amplification of $E$. trisella DNA in a positive control and two environmental water samples (Table 2). The positive control DNA sample collected from E. trisella tissue matched across its entirety to an E. trisella voucher specimen. The two eDNA fragments matched $E$. trisella DNA across $>95.0 \%$ of nucleotides with over $98.0 \%$ sequence coverage. One environmental sample however, did not match to E. trisella and the source of the eDNA molecule(s) sequenced could not be resolved. The sequence showed $91.49 \%$ nucleotide identity to the bacterium Rahnella aquatilis, but at only $16.0 \%$ coverage. In thirteen instances, environmental negative controls screened positive. Attempts to extract positive bands from an agarose gel for sequencing were inconclusive and did not provide any usable data. The number of environmental negative controls that screened positive did not show an association with collector $(\mathrm{p}=0.3834)$.

\section{DISCUSSION}

Using noninvasive methods for the surveillance of imperiled species is an attractive alternative to traditional methods, and we have presented our contribution to this innovation. We screened 256 water samples from Alabama and Georgia for E. trisella eDNA and were able to detect their presence using our LAMP protocol. A comparable study was completed that assessed E. trisella presence using eDNA and PCR in some of the same Alabama streams which showed fewer positive detections (1.3\%) than we reported here $(24.5 \%)$ (Johnston \& Janosik, 2019).

In verifying that our field and laboratory protocols were sufficient to detect E. trisella eDNA, we tested several positive controls known to contain E. trisella DNA. Because our primer design was broad enough to 
amplify DNA in positive control fish from different genetic populations, we infer that our methods should be capable of detecting fish from any of our localities. Including the proportion of negative environmental controls, we were also able to rule out bias in detection from the investigator $(\mathrm{p}=0.3834)$. From these data we conclude that all samples were handled in a similar fashion through the point of collection, transport, and processing.

The protocol that we designed includes several checks to determine if false positives are present. Our pipeline required negative and positive controls as well as cleaning lab equipment with bleach solution as described above. We also sequenced positive samples to verify the DNA source. We detected E. trisella presence in $34.2 \%$ of the environmental negative controls implemented $(\mathrm{n}=38)$. We were unable to isolate and sequence DNA fragments from these samples, but hypothesize that amplification in negative controls may result from contamination or amplification of eDNA from other sources. The incidence of false positives in LAMP studies has been previously documented in disease prevalence studies including that of malaria and thalassemia (Kollenda et al., 2018; Wang et al., 2020). The addition of quenched fluorescent primers to LAMP has been suggested to reduce the number of false positives(Hardinge \& Murray, 2019). Our reusable, bleached filter funnels are a potential source of contamination, and closed filters are an alternative that may reduce risks (Spens et al., 2017). Although our primers were designed with specificity for E. trisella, the LAMP protocol may cross-amplify DNA of other unintended targets. We determined that our primers matched E. trisella along the entirety of the cyt $b$ gene and mismatched E. jordani and $E$. rupestre at multiple nucleotides (18 and 26 sites respectively). We have shown that our primers show high specificity for the intended target, and are not a likely source of false positives. We postulate that environmental negative control water samples taken at Shoal Creek on the Cahaba River screened positive due to contamination or cross-amplification of a target not yet documented in genetic databases. Inspection of the eDNA sequence that matched poorly toRahnella aquatilis showed no sites that were likely for binding of our primers. We consider this sequence unresolved and not explicitly identified as Rahnella aquatilis .

We stress that caution should be used when interpreting negative results. Thus, the lack of detection at sites does not necessarily indicate that E. trisella are not present at those localities, but that our methods did not detect their presence. When utilizing eDNA, false negatives may arise because template DNA is not amplified using molecular methods despite presence of the target organism (Darling \& Mahon, 2011). Failure to amplify template DNA may occur because of DNA degradation, low quality or quantity DNA, low primer specificity, PCR inhibitors, and failed reactions (Klymus et al., 2015; Nathan et al., 2015). In addition, replicates are required to accurately determine diversity and detect rare species (Fonseca, 2018).

We report that detection probabilities varied significantly with the date of collection, with the number of detections increasing at the end of our collection period (i.e., expected end of spawning period). The life history of E. trisella may play a particularly strong role in why detections varied over time. E. trisella move between main and spawning channels. Although we did sample from potential spawning grounds throughout the expected spawning season, it is possible that our collections did not coincide with the fish's movement. Perhaps, E. trisella were not yet present at sites sampled early in the spawning season. Furthermore, DNA molecules may not be distributed homogenously in water bodies due to the number of organisms upstream, river flow rate, and the degree of water column mixing (Jerde et al., 2011). Duplicate samples from the same localities over time would be useful in clarifying this postulation. We plan to collect additional water samples as well as conduct confirmatory surveys to capture live E. trisella specimens coinciding with sites described here.

We have presented here our novel approach to noninvasive surveillance of freshwater species. Our protocol has provided evidence that loop-mediated isothermal amplification is a robust method for detecting low quantities of eDNA in the water and can be modified for application in other systems. We acknowledge that results of eDNA surveillance efforts should be interpreted with caution and require subsequent sequencing to confirm detection of the intended target.

\section{ACKNOWLEDGEMENTS}


This publication was made possible through a grant (62429) from the National Fish and Wildlife Foundation (NFWF), with funding provided by the U.S. Fish and Wildlife Service, the U.S. Forest Service, and Southern Company. A cost share was contributed by the Geological Survey of Alabama. The views and conclusions contained in this document are those of the authors and should not be interpreted as representing the opinions or policies of the U.S. Government, NFWF, or Southern Company. Mention of trade names or commercial products does not constitute their endorsement by the U.S. Government or NFWF or its funding sources. We thank Kenny Jones, John Larrimore, Brianna Forrest, Anna Eastis, Autumn Younge, and Dominque Dawson for filtering water and extracting eDNA and R. Parker Nenstiel and Peter Dimmick for water sample collection. We thank Brett Albanese for help with grant management.

\section{DATA ACCESSIBILITY STATEMENT}

All sequences are available on Genbank under the following accession numbers: MT490609, MT490610, and MT490611.

\section{AUTHOR CONTRIBUTIONS}

The research project was designed by MWS with contributions from authors; water samples were collected by AP; laboratory work and analyses were designed and conducted by KMF and MWS; and the paper was written by KMF with contributions from all of the authors.

\section{REFERENCES}

Altschul, S. F., Gish, W., Miller, W., Myers, E. W., \& Lipman, D. J. (1990). Basic local alignment search tool. Journal of Molecular Biology , 215 (3), 403-410.

Boschung, H. T., \& Mayden, R. L. (2004). Fishes of Alabama . Smithsonian Books.

Cilleros, K., Valentini, A., Allard, L., Dejean, T., Etienne, R., Grenouillet, G., Iribar, A., Taberlet, P., Vigouroux, R., \& Brosse, S. (2019). Unlocking biodiversity and conservation studies in high-diversity environments using environmental DNA (eDNA): A test with Guianese freshwater fishes. Molecular Ecology Resources ,19 (1), 27-46. https://doi.org/10.1111/1755-0998.12900

Darling, J. A., \& Mahon, A. R. (2011). From molecules to management: Adopting DNA-based methods for monitoring biological invasions in aquatic environments. Environmental Research , 111 (7), 978-988. https://doi.org/10.1016/j.envres.2011.02.001

Dejean, T., Valentini, A., Miquel, C., Taberlet, P., Bellemain, E., \& Miaud, C. (2012). Improved detection of an alien invasive species through environmental DNA barcoding: The example of the American bullfrog Lithobates catesbeianus. Journal of Applied Ecology ,49 (4), 953-959. https://doi.org/10.1111/j.13652664.2012.02171.x

Díaz-Ferguson, E. E., \& Moyer, G. R. (2014). Http://www.scielo.sa.cr/scielo.php?script=sci_abstract\&pid=S0034-77442014000400002\&lng=en\&nrm=iso\&tlng=pt.Revista de Biología Tropical , 62 (4), 1273-1284.

Drinkwater, R., Schnell, I. B., Bohmann, K., Bernard, H., Veron, G., Clare, E., Gilbert, M. T. P., \& Rossiter, S. J. (2019). Using metabarcoding to compare the suitability of two blood-feeding leech species for sampling mammalian diversity in North Borneo.Molecular Ecology Resources , 19 (1), 105-117. https://doi.org/10.1111/1755-0998.12943

Endangered and Threatened Wildlife and Plants; Threatened Species Status for Trispot Darter . (2018, December 28). Federal Register. https://www.federalregister.gov/documents/2018/12/28/201827971/endangered-and-threatened-wildlife-and-plants-threatened-species-status-for-trispot-darter

FishMap.org . (2018). [Fish Distribution Database]. FishMap.Org. http://fishmap.org/

Fonseca, V. G. (2018). "Pitfalls in relative abundance estimation using eDNA metabarcoding." Molecular Ecology Resources , 18 (5), 923-926. https://doi.org/10.1111/1755-0998.12902 
Foote, A. D., Thomsen, P. F., Sveegaard, S., Wahlberg, M., Kielgast, J., Kyhn, L. A., Salling, A. B., Galatius, A., Orlando, L., \& Gilbert, M. T. P. (2012). Investigating the Potential Use of Environmental DNA (eDNA) for Genetic Monitoring of Marine Mammals. PLOS ONE ,7 (8), e41781. https://doi.org/10.1371/journal.pone.0041781

Goldberg, C. S., Pilliod, D. S., Arkle, R. S., \& Waits, L. P. (2011). Molecular Detection of Vertebrates in Stream Water: A Demonstration Using Rocky Mountain Tailed Frogs and Idaho Giant Salamanders.PLOS ONE , 6 (7), e22746. https://doi.org/10.1371/journal.pone.0022746

Goldberg, C. S., Turner, C. R., Deiner, K., Klymus, K. E., Thomsen, P. F., Murphy, M. A., Spear, S. F., McKee, A., Oyler-McCance, S. J., Cornman, R. S., Laramie, M. B., Mahon, A. R., Lance, R. F., Pilliod, D. S., Strickler, K. M., Waits, L. P., Fremier, A. K., Takahara, T., Herder, J. E., \& Taberlet, P. (2016). Critical considerations for the application of environmental DNA methods to detect aquatic species. Methods in Ecology and Evolution, 7 (11), 1299-1307. https://doi.org/10.1111/2041-210X.12595

Grey, E. K., Bernatchez, L., Cassey, P., Deiner, K., Deveney, M., Howland, K. L., Lacoursiere-Roussel, A., Leong, S. C. Y., Li, Y., Olds, B., Pfrender, M. E., Prowse, T. A. A., Renshaw, M. A., \& Lodge, D. M. (2018). Effects of sampling effort on biodiversity patterns estimated from environmental DNA metabarcoding surveys. Scientific Reports ,8 (1), 1-10. https://doi.org/10.1038/s41598-018-27048-2

Hardinge, P., \& Murray, J. A. H. (2019). Reduced False Positives and Improved Reporting of LoopMediated Isothermal Amplification using Quenched Fluorescent Primers. Scientific Reports , 9 (1). https://doi.org/10.1038/s41598-019-43817-z

Jerde, C. L., Mahon, A. R., Chadderton, W. L., \& Lodge, D. M. (2011). "Sight-unseen" detection of rare aquatic species using environmental DNA. Conservation Letters , 4 (2), 150-157. https://doi.org/10.1111/j.1755-263X.2010.00158.x

Klymus, K. E., Richter, C. A., Chapman, D. C., \& Paukert, C. (2015). Quantification of eDNA shedding rates from invasive bighead carp Hypophthalmichthys nobilis and silver carp Hypophthalmichthys molitrix.Biological Conservation , 183 , 77-84. https://doi.org/10.1016/j.biocon.2014.11.020

Kollenda, H., Hagen, R. M., Hanke, M., Rojak, S., Hinz, R., Wassill, L., Poppert, S., Tannich, E., \& Frickmann, H. (2018). Poor Diagnostic Performance of a Species-Specific Loop-Mediated Isothermal Amplification (LAMP) Platform for Malaria. European Journal of Microbiology and Immunology , 8 (4), 112-119. https://doi.org/10.1556/1886.2018.00020

LAMP primer designing software:PrimerExplorer . (2015). http://primerexplorer.jp/lampv5e/index.html

Layton, A., McKay, L., Williams, D., Garrett, V., Gentry, R., \& Sayler, G. (2006). Development of Bacteroides 16S rRNA Gene TaqMan-Based Real-Time PCR Assays for Estimation of Total, Human, and Bovine Fecal Pollution in Water. Applied and Environmental Microbiology ,72 (6), 4214-4224. https://doi.org/10.1128/AEM.01036-05

Lee, P. L. M. (2017). DNA amplification in the field: Move over PCR, here comes LAMP. Molecular Ecology Resources , 17 (2), 138-141. https://doi.org/10.1111/1755-0998.12548

Mahon, A. R., Jerde, C. L., Galaska, M., Bergner, J. L., Chadderton, W. L., Lodge, D. M., Hunter, M. E., \& Nico, L. G. (2013). Validation of eDNA Surveillance Sensitivity for Detection of Asian Carps in Controlled and Field Experiments. PLOS ONE , 8 (3), e58316. https://doi.org/10.1371/journal.pone.0058316

Nagler, M., Insam, H., Pietramellara, G., \& Ascher-Jenull, J. (2018). Extracellular DNA in natural environments: Features, relevance and applications. Applied Microbiology and Biotechnology ,102 (15), 6343-6356. https://doi.org/10.1007/s00253-018-9120-4

Nathan, L. R., Jerde, C. L., Budny, M. L., \& Mahon, A. R. (2015). The use of environmental DNA in invasive species surveillance of the Great Lakes commercial bait trade. Conservation Biology , 29 (2), 430-439. https://doi.org/10.1111/cobi.12381 
Notomi, T., Okayama, H., Masubuchi, H., Yonekawa, T., Watanabe, K., Amino, N., \& Hase, T. (2000). Loop-mediated isothermal amplification of DNA. Nucleic Acids Research , 28 (12), e63-e63. https://doi.org/10.1093/nar/28.12.e63

Ogram, A., Sayler, G. S., \& Barkay, T. (1987). The extraction and purification of microbial DNA from sediments. Journal of Microbiological Methods , 7 (2), 57-66. https://doi.org/10.1016/0167-7012(87)90025$\mathrm{X}$

O'Neil, P. E., Shepard, T. E., Johnson, C. C., Spadgenske, E., \& Powell, J. (2009). Rediscovery of the Trispot Darter, Etheostoma trisella, in Alabama. Geological Survey of Alabama.

Page, L. M., \& Burr, B. M. (2011). Peterson Field Guide to Freshwater Fishes of North America North of Mexico . Houghton Mifflin Harcourt.

Paul, J. H., Kellogg, C. A., \& Jiang, S. C. (1996). Viruses and DNA in Marine Environments. In R. R. Colwell, U. Simidu, \& K. Ohwada (Eds.), Microbial Diversity in Time and Space (pp. 115-124). Springer US. https://doi.org/10.1007/978-0-585-34046-3_14

Pietramellara, G., Ascher, J., Borgogni, F., Ceccherini, M. T., Guerri, G., \& Nannipieri, P. (2009). Extracellular DNA in soil and sediment: Fate and ecological relevance. Biology and Fertility of Soils ,45 (3), 219-235. https://doi.org/10.1007/s00374-008-0345-8

R Core Team. (2018). R: A Language and Environment for Statistical Computing. R Foundation for Statistical Computing. http://www.R-project.org/

Rare Species Status Maps . (2020, January 28). Rare Species Status Maps. https://georgiabiodiversity.a2hosted.com/natels/rangemaps?es_id=20635

Rees, H. C., Maddison, B. C., Middleditch, D. J., Patmore, J. R. M., \& Gough, K. C. (2014). REVIEW: The detection of aquatic animal species using environmental DNA - a review of eDNA as a survey tool in ecology.Journal of Applied Ecology , 51 (5), 1450-1459. https://doi.org/10.1111/1365-2664.12306

Ryon, M. G. (1986). The Life History and Ecology of Etheostoma trisella (Pisces: Percidae). The American Midland Naturalist ,115 (1), 73-86. https://doi.org/10.2307/2425838

Sandel, M. W., Fast, K. M., Albanese, B., Popp, A., Nensteil, P., \& Sudmant, P. (2020). Complete Mitochondrial Genome of the Imperiled Trispot Darter (Etheostoma trisella). Mitochondrial DNA Part B . Advance online publication.

Spens, J., Evans, A. R., Halfmaerten, D., Knudsen, S. W., Sengupta, M. E., Mak, S. S. T., Sigsgaard, E. E., \& Hellstrom, M. (2017). Comparison of capture and storage methods for aqueous macrobial eDNA using an optimized extraction protocol: Advantage of enclosed filter.Methods in Ecology and Evolution , 8 (5), 635-645. https://doi.org/10.1111/2041-210X.12683

Taberlet, P., Coissac, E., Hajibabaei, M., \& Rieseberg, L. H. (2012). Environmental DNA. Molecular Ecology , 21 (8), 1789-1793. https://doi.org/10.1111/j.1365-294X.2012.05542.x

Wang, W., Lin, M., Li, H., Huang, J., Chen, J., Fang, X., Huang, D., Xi, X., Zhao, Q., Song, F., Huang, S., \& Zhong, T. (2020). Establishment and Evaluation of a Novel Method Based on Loop-Mediated Isothermal Amplification for the Rapid Diagnosis of Thalassemia Genes. Risk Management and Healthcare Policy , 13 , 303-311. https://doi.org/10.2147/RMHP.S241399

Wilcox, T. M., McKelvey, K. S., Young, M. K., Sepulveda, A. J., Shepard, B. B., Jane, S. F., Whiteley, A. R., Lowe, W. H., \& Schwartz, M. K. (2016). Understanding environmental DNA detection probabilities: A case study using a stream-dwelling char Salvelinus fontinalis.Biological Conservation , 194 , 209-216. https://doi.org/10.1016/j.biocon.2015.12.023

Ye, J., Coulouris, G., Zaretskaya, I., Cutcutache, I., Rozen, S., \& Madden, T. L. (2012). Primer-BLAST: A tool to design target-specific primers for polymerase chain reaction. BMC Bioinformatics ,13 , 134. 
https://doi.org/10.1186/1471-2105-13-134

\section{Hosted file}

E tris Mol Eco map 6-11-20.docx available at https://authorea.com/users/346494/articles/ 472468-surveillance-of-a-federally-protected-freshwater-fish-using-loop-mediatedisothermal-amplification-lamp-and-edna

\section{Hosted file}

E tris Mol Eco primers table 6-11-20.docx available at https://authorea.com/users/346494/ articles/472468-surveillance-of-a-federally-protected-freshwater-fish-using-loopmediated-isothermal-amplification-lamp-and-edna

\section{Hosted file}

E tris Mol Eco identity table 6-11-20.docx available at https://authorea.com/users/346494/ articles/472468-surveillance-of-a-federally-protected-freshwater-fish-using-loopmediated-isothermal-amplification-lamp-and-edna 